Selcuk Journal of Agriculture and Food Sciences

http://sjafs.selcuk.edu.tr/sjafs/index

Research Article
SJAFS

(2021) 35 (2), 83-90

e-ISSN: $2458-8377$

DOI:10.15316/SJAFS.2021.232

\title{
Short-Term Impacts of Biochar Applications on Physico-Mechanic and Chemical Properties af Two Contrasting Textured Soils
}

\author{
iD Qutaiba Riyadh ABDULWAHHAB ${ }^{1}$, iD Cevdet ŞEKER ${ }^{2}$ \\ ${ }^{1}$ Tikrit University, Faculty of Agriculture, Department of Soil Science and Water Rescores, Tikrit, Iraq \\ ${ }^{2}$ Selçuk University, Faculty of Agriculture, Department of Soil Science and Plant Nutrition, Konya, Turkey
}

\begin{tabular}{l}
\hline ARTICLE INFO \\
\hline Article history: \\
Received date: 10.02 .2021 \\
Accepted date: 14.04 .2021 \\
\hline
\end{tabular}

Keywords:

Biochar

Soil Aggregation

Soil Texture

Carbon Sequestration

\begin{abstract}
The effect of biochar applications on soil properties varies significantly depending on soil textures. Therefore, a pot experiment was carried out to investigate the effects of biochar (BC) amendment on some soil physico-mechanic and chemical properties, such as bulk density (BD), particle density (PD), mean weight diameter (MWD), aggregate stability (AS), Attarberg limits, soil $\mathrm{pH}$, electric conductivity (EC), organic carbon (OC), total nitrogen (TN), and $\mathrm{C}: \mathrm{N}$ ratio of two different textured calcareous soils (Clay and Sandy Loam). Biochar produced from sunflower residues were mixed with soils at the rate of $0,1,2$ and $4 \%$. All pots were watered to field capacity and incubated for 30 days. The results showed that biochar improved soil structural properties for both studied soils. Although mean weight diameter (MWD) was increased in clay soil, it was decreased in sandy loam soil. The liquid limit was increased by an increment of $\mathrm{BC}$ application rates in both soils, and the plastic limit was increased in single clay soil. BC affected selected soil chemical properties by decreasing soil $\mathrm{pH}$, and increasing the soil $\mathrm{EC}, \mathrm{OC}, \mathrm{TN}$, and $\mathrm{C}: \mathrm{N}$ ratio, but no effect was detected on $\mathrm{CaCO}_{3}$ content in both soils. Organic carbon mineralization ratio increased in the clay soil amended with $\mathrm{BC}$, however, decreased in the sandy loam soil compared with the control sample. As a conclusion, the biochar amendment improved soil physico-mechanic properties of the studied soils. However, the effect on chemical properties was inconsistent
\end{abstract}

\section{Introduction}

Biochar is a charcoal produced by pyrolysis of biomass in a closed container at relatively low temperatures $\left(<700^{\circ} \mathrm{C}\right)$ with restricted oxygen conditions (Lehmann and Joseph, 2009). Biochar amendment can mitigate the impact of climate change and is regarded as a promising strategy for soil carbon (C) sequestration (Lehmann 2007; Woolf et al. 2010). Due to its stability and low degradation rate in soil compare with other common organic matter resources, its effect on soil physical, chemical and biological properties may continue for a long time period (Atkinson et al. 2010).

The high porosity and a high surface area exceeding $400 \mathrm{~m}^{2} \mathrm{~g}^{-1}$ of biochar were reported by (Brown et al. 2006), and thereby increasing the holding capacity of water and nutrient in soil (Ippolito et al. 2011). The results of many researchers showed that biochar amendment reduced soil bulk density by increase soil porosity and aeration (Tammeorg et al. 2014; Omondi et al. 2016). It helped to improve soil structure by producing more stable soil aggregate through the promo-

\footnotetext{
*Corresponding author email: cseker@selcuk.edu.tr
}

tion of macroaggregate formation (Herath et al. 2013; Ouyang et al. 2013). Soil structure stability is affected by different factors, such as clay content, and amount and type of soil organic matter (Six et al. 2004). The stability of soil aggregate can protect soil organic matter by reducing the decomposition (Six et al. 2002).

Increasing of organic matter content by the addition of biochar can significantly enhance soil microbial activity, which plays the main role for stabilization and formation of soil macroaggregates (Lehmann and Joseph 2009). The increase in aggregate stability by addition of biochar was associated with an increase in physically protected $\mathrm{C}$ incorporated in macroaggregates at fine textured silt loam soil; however, at coarse-textured sandy loam soil biochar had no effect on aggregation (Wang et al. 2017). Pituello et al. (2018), found that promoting of aggregate stability by addition of biochar improve the physical fertility of the soil, especially with coarse-textured and low organic carbon contented soils. Soil conditions and feedstocks of tested biochars were effective in improving soil properties (Omondi et al. 2016).

Due to the role of biochar in increasing soil water holding capacity by increasing soil porosity, it has a 
certain effect in the limits of Atterberg (liquid and plastic limits), however, no more studies had explained biochar amendment effect on these limits adequately. About the effect of biochar on soil chemical properties, there is high variability of the result depends on the biomass used, the temperature during pyrolysis and residence time (Teßin, 2016). Biochar usually has alkaline $(\mathrm{pH}>7)$ activity (Lehmann and Joseph 2009), high ash contents, and high surface areas and could result in increased soil $\mathrm{pH}$ as reported by Novak et al. (2009). Thus, a lot of studies investigated about the effect of biochar amendment on acidic soil showed that soil $\mathrm{pH}$ was increased, e.g., (Tasneem and Zahir 2017). High content of ash in biochar can increase soil $\mathrm{pH}$, due to the presence of readily soluble oxides of $\mathrm{CaO}, \mathrm{MgO}$, $\mathrm{Fe}_{2} \mathrm{O}_{3}$ in biochar (Koukouzas et al. 2007). However, oxidation of biochar could decrease the $\mathrm{pH}$ of the soil around the vicinity of biochar particles (Cheng et al. 2006). Soil EC increased significantly with biochar amendment in most of the research. This increase was attributed to the release of weakly bound nutrients of biochar in the soil solution (Chintala et al. 2013).

The $\mathrm{C}$ : $\mathrm{N}$ ratios of biochar vary widely and ranged between 7-400, with a high mean of 61 , and it is considered as a high $\mathrm{N}$ depleted (Lehmann and Joseph 2009). Since, C: $N$ ratios increase immobilization of $N$ occurs, biochar amendment to the soil add a supplemental amount to the both $\mathrm{C}$ and $\mathrm{N}$ stock (Clough et al. 2013). The mineralization of organic matter in the soil during the incubation period is an important indicator of soil microorganism activity. The objective of this study was to determine the short-term effects of biochar applications doses on improving the physicomechanic and chemical properties of two different contrasting textured soils having poor aggregation properties.

\section{Materials and Methods}

\section{Site description and soil sampling}

Agricultural soil located at Central of Anatolia region, Konya plain $(1016 \mathrm{~m} \mathrm{H})$, where clay soil from Saricalar Research and Application Farm $\left(38^{\circ} 05^{\prime} 48.0^{\prime \prime} \mathrm{N}, 32^{\circ} 26^{\prime} 23.0^{\prime \prime} \mathrm{E}\right)$, and sandy loam from a soil plot at Çumra basin $\left(37^{\circ} 33^{\prime} 38.3^{\prime \prime} \mathrm{N}, 32^{\circ} 40^{\prime} 00.0^{\prime \prime} \mathrm{E}\right)$ under cultivation were collected from the surface (0-20 $\mathrm{cm}$ ) and used in this study (Table 1). Both textured soil samples used in the study were weak aggregated properties and low exchangeable-extractable sodium contents and with alkali reaction and no salinity problems (Bal et al. 2011; Şeker et al. 2016). Soil samples were sieved in situ by $4 \mathrm{~mm}$ sieve, and then after air-drying part of samples passed through a $2 \mathrm{~mm}$ sieve and experiment establishment at the laboratory in April 2018.

\section{Preparation of biochar}

Biochar produced from sunflower residues, and before the pyrolysis process dried in an oven at $70^{\circ} \mathrm{C}$ for 24 hours to remove moisture, thereafter, wrapped with aluminum foil to prevent the entrance of oxygen and then pyrolyzed in a muffle furnace at a temperature of $450^{\circ} \mathrm{C}$ for one hour. After cooling, the biochar was passed through $2 \mathrm{~mm}$ sieve and stored in a plastic container until the starting of the experiment. Biochar was a very high alkaline reaction ( $\mathrm{pH}: 10.2)$ and $\mathrm{EC}$ value and $\mathrm{C} / \mathrm{N}: 25,9$ (Table 1)

Table 1

Properties of soil and used material.

\begin{tabular}{lccc}
\hline Soil parameters & $\begin{array}{c}\text { Clay } \\
\text { soil }\end{array}$ & $\begin{array}{c}\text { Sandy } \\
\text { loam soil }\end{array}$ & Biochar \\
\hline Clay $(\%)$ & 50.70 & 8.60 & - \\
Silt $(\%)$ & 36.00 & 14.00 & - \\
Sand $(\%)$ & 13.30 & 77.40 & - \\
$\mathrm{pH}^{*}, * *$ & 8.0 & 8.2 & 10.2 \\
$\mathrm{EC}^{*} * *\left(\mathrm{dS} \mathrm{m}^{-1}\right)$ & 0.6 & 0.3 & 15.0 \\
$\mathrm{CaCO}_{3}(\%)$ & 13.2 & 11.9 & 10.6 \\
$\mathrm{OC}(\%)$ & 2.3 & 0.9 & 62.1 \\
$\mathrm{~N}(\%)$ & 0.2 & 0.1 & 2.4 \\
$\mathrm{C} / \mathrm{N}$ & 13.9 & 8.7 & 25.9 \\
Field cap. $\left(\mathrm{g} \mathrm{g}^{-1}\right)$ & 0.37 & 0.20 & - \\
*(1:2.5) Dilution rate for soils, **(1:20) dilution rate for biochar \\
Incubation experiment setup
\end{tabular}

Soil samples of $3 \mathrm{~kg}$ based on a dry weight basis were completely mixed with biochar (BC) at a rate of $0 \%$ (control), 1,2 and $4 \%$ for both soil texture, the mixtures were placed in the pots, then watered at field capacity and subsequently incubated for 30 days at $23 \pm 2{ }^{\circ} \mathrm{C}$. During the incubation period, after every 3 days, water losses were compensated by adding deionized water up to field capacity.

Statistical Analyses

The study was a pot experiment with four replications in accordance with a completely randomized plot design, and all data (means \pm standard deviation) were analyzed by one-way ANOVA, and differences in means were compared by the least significant difference test at $\mathrm{P}<0.05$. All statistical analysis was carried out by (Minitab, 2013).

Soil Analyses

Soil texture was determined by Bouyoucos hydrometer method (Gee and Bauder, 1986). Soil bulk density (BD) was measured through the protocol developed by Jacobs et al. (1964), particle density (PD) was measured by pycnometer method (Blake and Hartge, 1986), and then soil total porosity was calculated by the relation between BD and PD (Danielson and Sutherland, 1986). Soil aggregation status was studied by a wet sieving method adapted by (Kemper and Rosenau, 1986). At the end of the incubation period, dry soil samples passed through a sieve of $4 \mathrm{~mm}$, then put on the top of $(2,1,0.5$ and $0.25 \mathrm{~mm})$ sieves, then transported to the Yoder machine and sieved for 10 minutes. Mean weight diameter (MWD), an index of soil aggregate stability was calculated according to the following equation (van Bavel, 1950):

$M W D=\sum_{i=1}^{n} X i * W i$

Where: $\mathrm{Xi}$ is the average diameter $(\mathrm{mm})$ for particles in its fraction and $\mathrm{Wi}$ is the weight percentage of the fraction in the whole soil. 
Aggregate stability values were determined by artificial rainfall simulator according to Gugino et al. (2009). The liquid limit was measured by penetrometer method after passing soil samples from $0.42 \mathrm{~mm}$ mesh sieve according to (TSE 1987). Plastic limit (PL), Liquid limit (LL) and Plasticity index (PI) was determined through an established method by (ASTM, 2010). Soil $\mathrm{pH}$ and electric conductivity (EC) $(1: 2.5)$ were measured in the laboratory after the end of incubation (Mclean 1982; Rhoades 1982). Calcium carbonate $\left(\mathrm{CaCO}_{3}\right)$ was determined by reaction with dilute hydrochloric acid in Scheibler calcium, by measuring the volume of emitted $\mathrm{CO}_{2}$ from carbonates (Nelson 1982). Soil organic carbon (OC) was measured by a wet combustion method proposed by Smith and Weldon (1941). Total Nitrogen (TN) was determined by using the LECO CN-2000 device with Dumas dry burning method (Wright and Bailey, 2001). The mineralization rate of $\mathrm{OC}$ was detected in control treatments by calculating the rate between the inherent soil $\mathrm{OC}$ before incubation and the OC after one month of incubation, and for the $\mathrm{BC}$ doses by adding the contributing amount came from $\mathrm{BC}$ before and after the incubation period.

\section{Results and Discussion}

\section{Physico-mechanic properties}

The effect of biochar amendment at rates of 1,2 and $4 \%$ on soil physico-mechanic properties of clay Table 2

Effect of biochar on soil physical properties in clay and sandy loam soil

\begin{tabular}{|c|c|c|c|c|c|}
\hline \multirow{2}{*}{ Properties } & \multicolumn{4}{|c|}{ Clay soil } & \multirow{2}{*}{$\begin{array}{c}\mathrm{P} \\
\text { Value }\end{array}$} \\
\hline & Control & $1 \%$ & $2 \%$ & $4 \%$ & \\
\hline Bulk density $\left(\mathrm{g} \mathrm{cm}^{-3}\right)$ & $0.95 \pm 0.00 \mathrm{a}$ & $0.91 \pm 0.00 \mathrm{~b}$ & $0.91 \pm 0.00 \mathrm{~b}$ & $0.91 \pm 0.00 \mathrm{~b}$ & $* * *$ \\
\hline Particle density $\left(\mathrm{g} \mathrm{cm}^{-3}\right)$ & $2.56 \pm 0.00 \mathrm{a}$ & $2.58 \pm 0.01 \mathrm{a}$ & $2.56 \pm 0.01 \mathrm{a}$ & $2.49 \pm 0.02 \mathrm{~b}$ & $* * *$ \\
\hline Total porosity $(\%)$ & $0.62 \pm 0.00 \mathrm{~b}$ & $0.65 \pm 0.00 \mathrm{a}$ & $0.65 \pm 0.00 \mathrm{a}$ & $0.64 \pm 0.00 \mathrm{a}$ & $* * *$ \\
\hline $\operatorname{MWD}(\mathrm{mm})$ & $0.22 \pm 0.02 \mathrm{~b}$ & $0.29 \pm 0.04 \mathrm{a}$ & $0.31 \pm 0.04 \mathrm{a}$ & $0.33 \pm 0.03 \mathrm{a}$ & $* *$ \\
\hline \multirow[t]{2}{*}{ Aggregate stability (\%) } & $7.88 \pm 1.32 \mathrm{c}$ & $15.44 \pm 0.97 \mathrm{~b}$ & $17.82 \pm 1.26 \mathrm{a}$ & $13.65 \pm 0.79 \mathrm{~b}$ & $* * *$ \\
\hline & \multicolumn{4}{|c|}{ Sandy loam soil } & \\
\hline Bulk density $\left(\mathrm{g} \mathrm{cm}^{-3}\right)$ & $1.20 \pm 0.01 \mathrm{a}$ & $1.21 \pm 0.00 \mathrm{a}$ & $1.19 \pm 0.00 \mathrm{a}$ & $1.13 \pm 0.01 \mathrm{~b}$ & $* * *$ \\
\hline Particle density $\left(\mathrm{g} \mathrm{cm}^{-3}\right)$ & $2.50 \pm 0.03$ & $2.54 \pm 0.01$ & $2.53 \pm 0.01$ & $2.51 \pm 0.02$ & NS \\
\hline Total porosity (\%) & $0.52 \pm 0.00 \mathrm{~b}$ & $0.52 \pm 0.00 \mathrm{~b}$ & $0.53 \pm 0.00 \mathrm{~b}$ & $0.55 \pm 0.00 \mathrm{a}$ & $* * *$ \\
\hline $\operatorname{MWD}(\mathrm{mm})$ & $0.33 \pm 0.00 \mathrm{a}$ & $0.27 \pm 0.01 \mathrm{~b}$ & $0.23 \pm 0.04 \mathrm{bc}$ & $0.22 \pm 0.01 \mathrm{c}$ & $* * *$ \\
\hline Aggregate stability (\%) & $6.06 \pm 0.88 \mathrm{~b}$ & $8.40 \pm 0.53 \mathrm{a}$ & $6.67 \pm 1.26 \mathrm{ab}$ & $6.29 \pm 0.43 \mathrm{~b}$ & $* *$ \\
\hline
\end{tabular}

and sandy loam soils, such as bulk density, particle density, soil porosity, mean weight diameter, aggregate stability, liquid limit, plastic limit, and plastic index, which are presented in (Table 2). Soil bulk density was significantly decreased $(\mathrm{P}<0.001)$ with increasing of biochar rates for both soils texture compared with the control treatments (Table 2). There are no significant differences between application rates of biochar in clay soil; however, BC $4 \%$ decreased bulk density by $5.8 \%$ in sandy loam soil. Particle density was decreased significantly $(\mathrm{P}<0.001)$ in clay soil only at $\mathrm{BC} 4 \%$ and no significant effect on sandy loam soil. The results of total porosity obtained from the relation between bulk and particle density significantly $(\mathrm{P}<0.001)$ increased in both soil texture, but no significant effect between rates of $\mathrm{BC}$ in clay soil. In the sandy loam, total porosity was increased with increasing of $\mathrm{BC}$ amendments and the rate of $4 \%$ had the highest value.

The results of mean MWD in clay soil significantly $(\mathrm{P}<0.01)$ increased with increasing of $\mathrm{BC}$ rates and the highest MWD was found at $4 \%$ by being increased nearly $33 \%$, however, no significant effect between BC rates. Contrarily, in sandy loam soil, increasing of $\mathrm{BC}$ amendments affected negatively and significantly $(\mathrm{P}<0.001)$ decreased the MWD, and the lowest value was at $4 \%$ by being decreased by $33 \%$.
The results of AS obtained from rainfall simulator experiment showed significantly $(\mathrm{P}<0.001)$ increased with increasing of $\mathrm{BC}$ rates in clay soil, and highest AS was at $2 \%$ by being increased $126 \%$. Whereas in the sandy loam soil, AS significantly $(\mathrm{P}<0.01)$ increased $36.6 \%$ when only $1 \%$ of BC was applied, but no significant effect at $2 \%$ and $4 \%$ application rates. Figure 1 shows the effect of biochar doses on Atterberg limits in clay soil. The liquid limit results showed a significant increase $\left(\mathrm{R}^{2}: 0.97, \mathrm{P}<0.001\right)$ with an increase of $\mathrm{BC}$ rates, and the highest increase was $11 \%$ for clay soil when $4 \%$ rate was applied. The results of plastic limit were significantly increased $\left(\mathrm{R}^{2}: 0.99, \mathrm{P}<0.01\right)$ with an increase of $\mathrm{BC}$ doses and plastic limit increased by 


\section{Clay soil}

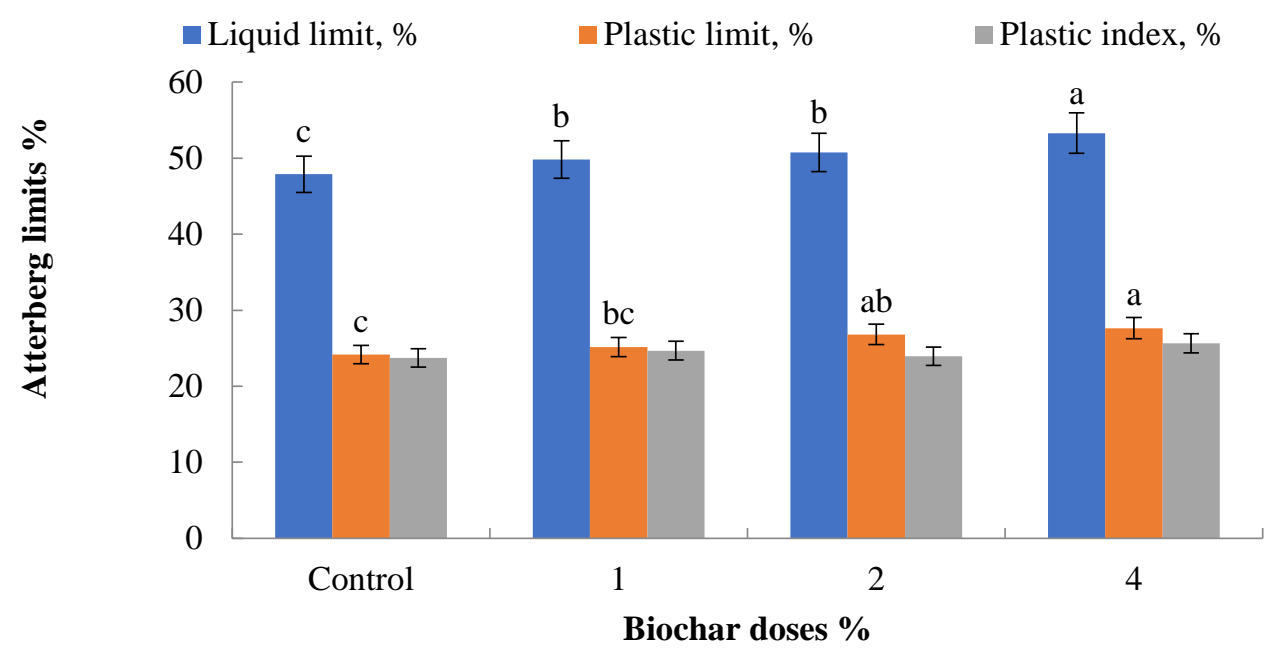

Figure 1

Illustration of liquid limit, plastic limit and plastic index of clay soil.

Table 3

Effect of biochar on soil chemical properties in clay and sandy loam soil

\begin{tabular}{|c|c|c|c|c|c|}
\hline \multirow{2}{*}{ Properties } & \multicolumn{4}{|c|}{ Clay soil } & \multirow{2}{*}{$\begin{array}{l}\mathrm{P} \\
\text { Value }\end{array}$} \\
\hline & Control & $1 \%$ & $2 \%$ & $4 \%$ & \\
\hline $\mathrm{pH}\left(1: 2.5 \mathrm{H}_{2} \mathrm{O}\right)$ & $8.02 \pm 0.00 \mathrm{a}$ & $7.89 \pm 0.02 \mathrm{~b}$ & $7.88 \pm 0.00 \mathrm{~b}$ & $7.85 \pm 0.00 \mathrm{c}$ & $* * *$ \\
\hline $\mathrm{EC}\left(1: 2.5 \mathrm{H}_{2} \mathrm{O} \mathrm{dS} \mathrm{m}^{-1}\right)$ & $0.57 \pm 0.03 \mathrm{~d}$ & $1.04 \pm 0.019 \mathrm{c}$ & $1.33 \pm 0.006 \mathrm{~b}$ & $2.07 \pm 0.078 \mathrm{a}$ & $* * *$ \\
\hline $\mathrm{OC}(\%)$ & $2.41 \pm 0.01 \mathrm{~d}$ & $2.95 \pm 0.03 \mathrm{c}$ & $3.34 \pm 0.08 \mathrm{~b}$ & $4.16 \pm 0.12 \mathrm{a}$ & $* * *$ \\
\hline $\mathrm{CaCO}_{3}(\%)$ & $13.23 \pm 0.56$ & $12.95 \pm 0.51$ & $13.26 \pm 0.63$ & $13.54 \pm 0.07$ & NS \\
\hline Total nitrogen $(\%)$ & $0.17 \pm 0.02 \mathrm{c}$ & $0.19 \pm 0.00 \mathrm{bc}$ & $0.21 \pm 0.01 \mathrm{ab}$ & $0.23 \pm 0.02 \mathrm{a}$ & $* * *$ \\
\hline \multirow[t]{2}{*}{$\mathrm{C} / \mathrm{N}$} & $10.15 \pm 1.91 \mathrm{~b}$ & $11.05 \pm 0.37 \mathrm{~b}$ & $12.23 \pm 1.11 \mathrm{ab}$ & $14.92 \pm 1.34 \mathrm{a}$ & $*$ \\
\hline & \multicolumn{4}{|c|}{ Sandy loam soil } & \\
\hline $\mathrm{pH}\left(1: 2.5 \mathrm{H}_{2} \mathrm{O}\right)$ & $8.20 \pm 0.01 \mathrm{a}$ & $8.07 \pm 0.01 \mathrm{~b}$ & $8.04 \pm 0.00 \mathrm{c}$ & $8.00 \pm 0.01 \mathrm{~d}$ & $* * *$ \\
\hline $\mathrm{EC}\left(1: 2.5 \mathrm{H}_{2} \mathrm{O}\right.$ ds. $\left.\mathrm{m}^{-1}\right)$ & $0.25 \pm 0.01 \mathrm{~d}$ & $0.62 \pm 0.02 \mathrm{c}$ & $1.03 \pm 0.01 \mathrm{~b}$ & $1.76 \pm 0.09 \mathrm{a}$ & $* * *$ \\
\hline $\mathrm{OC}(\%)$ & $0.92 \pm 0.01 \mathrm{~d}$ & $1.38 \pm 0.01 \mathrm{c}$ & $1.65 \pm 0.02 \mathrm{~b}$ & $2.58 \pm 0.02 \mathrm{a}$ & $* * *$ \\
\hline $\mathrm{CaCO}_{3}(\%)$ & $11.90 \pm 0.40$ & $11.66 \pm 0.27$ & $12.33 \pm 0.28$ & $12.31 \pm 0.40$ & NS \\
\hline Total nitrogen $(\%)$ & $0.12 \pm 0.00 \mathrm{c}$ & $0.16 \pm 0.00 \mathrm{~b}$ & $0.17 \pm 0.00 \mathrm{~b}$ & $0.18 \pm 0.00 \mathrm{a}$ & $* * *$ \\
\hline $\mathrm{C} / \mathrm{N}$ & $4.95 \pm 0.27 \mathrm{~d}$ & $6.73 \pm 0.32 \mathrm{c}$ & $11.38 \pm 0.93 \mathrm{~b}$ & $14.13 \pm 0.91 \mathrm{a}$ & $* * *$ \\
\hline
\end{tabular}

Significant at $* P<0.05, * * * P<0.001 ;$ NS: Not significant.

The EC values were significantly $(\mathrm{P}<0.001)$ increased with increasing of $\mathrm{BC}$ rates in both soils of the study, and the rate of $4 \%$ had the highest $\mathrm{EC}$ value, which was increased by $263 \%$ and $604 \%$ in clay and sandy loam soils, respectively. $\mathrm{CaCO} 3$ content was not affected by the addition of $\mathrm{BC}$ in both soils. TN was increased significantly $(\mathrm{P}<0.001)$ by increasing $\mathrm{BC}$ rates in both soils, and the highest increase of TN was at $4 \%$ of $\mathrm{BC}$ in both soils, by a rate of $35.3 \%$ and $50 \%$ in clay and sandy loam soils, respectively. OC takes the same trend of nitrogen by significant increasing $(\mathrm{P}<0.001)$ with an increase of $\mathrm{BC}$, and the highest values were at a rate of $4 \%$ by increasing rate of $72.6 \%$ and $180 \%$ in clay and sandy loam soils, respectively. The relationship between carbon and nitrogen which is expressed as $\mathrm{C} / \mathrm{N}$ ratio showed a significant $(\mathrm{P}<0.05$ and $\mathrm{P}<0.001$ ) increase in clay soil and sandy loam soil with increasing of $\mathrm{BC}$. It was found that the highest applied dose showed a higher value of $\mathrm{C} / \mathrm{N}$ and $\mathrm{C} / \mathrm{N}$ increased respectively by 47 and $185.4 \%$ in sandy loam and clay soil when biochar was applied at a rate of $4 \%$. The mineralization rate of $\mathrm{OC}$ at the end of the shortterm incubation period (one month) as illustrated in figure 3 and 4 was $11.5 \%$ at the clay soil, and $43 \%$ at sandy loam soil in control treatments, whereas at the $\mathrm{BC}$ amendments of 1,2 , and $4 \%$, the mineralized OC was significantly increased $(\mathrm{P}<0.001)$ by the means of $23.9,21.1$, and $23.3 \%$ in a clay soil, and significantly decreased $(\mathrm{P}<0.001)$ by the means of $34.6,15.8$, and $23.6 \%$ in a sandy loam soil, respectively.

\section{Discussion and conclusion}

In both soils, the short-term amendment effects of biochar applications on the physico-mechanical properties were limited even if they were found significant statistically. The bulk density was decreased with concurrently increasing of BC doses and soil porosity in fine and coarse-textured soils, and these results are compatible with other studies (Lehmann and Joseph, 2009; Glab et al. 2016; Ningning et al. 2016). Due to 
the low density of biochar around 1.5 to $1.7 \mathrm{~g} \mathrm{~cm}^{-3}$ (Oberlin 2002) and $1.47 \mathrm{~g} \mathrm{~cm}^{-3}$ such as biochar made from pine wood collected from fire site (Brown et al. 2006), the particle density of our soils with $4 \%$ of BC amendment was significantly decreased. One of the mechanisms of soil aggregation is made by forming cation bridges between clay particles and soil organic matter (Juriga and Šimanský, 2018). In addition, biochar has high basic cation content (Rajkovich et al. 2012), therefore, its application to the soil can join clay and organic particles together by cation bridges (Bronick and Lal, 2005). In this study, the aggregation index of MWD was significantly increased with increasing of biochar doses only in clay soil. In contrast to the results of sandy loam soil, it was shown that MWD decreased with increasing of BC doses because of the weak bond between sand particle, although both soils have low exchangeable-extractable sodium contents (Bal et al. 2011; Şeker et al. 2016), which made a weak soil aggregate that cannot resist the wet sieving. Our results about the effect of biochar on MWD in sandy loam soil are in agreement with Fungo et al. (2017), who found that biochar did not affect on MWD alone, but when a combined application with green manure or urea showed a significant increase in MWD. Similarly, Herath et al. (2015) and Peng et al. (2016) founds that no effect of biochar amendment on soil micro-aggregates. However, the results of soil aggregate stability by rainfall simulator showed a significant increase in values of both soils compare with control, meaning that biochar amendment promoted the formation of more stable soil aggregate, which is resistant to degradation by rainfall drops. But when biochar doses were increased up to $4 \%$ in clay soil, as well as up to 2 and $4 \%$ in sandy, soil aggregate decreased compare with $1 \%$, this was probably attributed to the effect of raindrops to reduce the particle size of biochar from certain types of biomass (Graetz and Skjemstad 2003). The liquid limit was significantly increased with increasing of BC doses in both soils. No more studies about the direct effect of BC on Atterberg limits have been carried out, however, it was reported that biochar can improve soil physical and hydraulic properties, such as soil porosity and soil water holding capacity (Şeker and Manirakiza 2020). Likewise, the result of the plastic limit in clay soil showed a significant increase for the same reason. Plasticity index results showed that there was no significant effect of $\mathrm{BC}$ amendment on soil plasticity; however, it was classified as plastic soils according to (Leonards 1962) classification. According to (Mitchell 1976) and depending on the results of Atterberg limits, the estimate clay mineral of our studied clay soil is kaolinite.

The $\mathrm{pH}$ of biochar considerably depends on the type of used feedstock and pyrolysis temperature, and it has been well documented that biochar amendment can significantly alter the $\mathrm{pH}$ of the soil (Lehmann and Joseph 2009). Although our results showed that $\mathrm{pH}$ of $\mathrm{BC}$ that used in this experiment was up to 10.2 , soil $\mathrm{pH}$ was significantly decreased with increasing of $\mathrm{BC}$ doses as compared with the control in both soils. Cheng et al. (2006) reported that $\mathrm{pH}$ of biochar can be decreased to a value of 2.5 after incubation at $70^{\circ} \mathrm{C}$ in a short time period of four months and attributed that to the effect of incubation on increasing of oxidization process, thereby decreasing soil $\mathrm{pH}$ around biochar particle. About the effect of $\mathrm{BC}$ amendment on soil EC, our results showed a remarkable increase in soil EC with increasing of $\mathrm{BC}$ doses, and these results are agreement with numbers of studies such as (Lehmann and Joseph 2009; Tasneem and Zahir 2017) this increase in soil EC could be attributed to the release of weakly bound nutrients of biochar in the soil solution (Chintala et al. 2013).

The OC was significantly increased with BC amendment in both soil, this was expected because of the high sequestration of $\mathrm{C}$ in biochar. The increasing rate was more in sandy loam soil than clay soil, because of the inherent low content of OC in sandy soil. The TN content was increased significantly in both soils, but the increasing rate was higher in sandy soil than clay soil. Our results of TN and OC are in agreement with Laird et al. (2010), who found that biochar amendment significantly increased $\mathrm{TN}$ and $\mathrm{OC}$. The $\mathrm{C} / \mathrm{N}$ ratio was significantly increased in both soils under cultivation with increasing of $\mathrm{BC}$, due to its high $\mathrm{C}$ content in biochar.

The results of mineralized OC illustrated in figures 3 and 4 have shown that the mineralization rate of control treatments in sandy loam soil was approximately fourfold more than that at a clay soil. This supposed to be because of the effect of clay by making colloidal complexes led to reducing the mineralization rate in clay soil (Six et al. 1998; Sparks 2003). Whereas at the $\mathrm{BC}$ amendments, our results have shown an increase in the mineralization rate of clay soil in comparison with control, however, it was relatively still at a stable rate with increase of BC doses, may be because of the high activity and number of microorganisms in clay soils still sufficient even in with increasing of OC in soil (Lehmann et al. 2011). While the opposite occurred in a sandy loam soil the BC amendments had an effect by decreasing the rate of mineralization in significantly compared with control, due to higher mineralization ratio of the control sample non-amended with $\mathrm{BC}$ at sandy loam soil. Although the organic carbon content of the sandy loam soil is lower than the clay soil, the mineralization rate in the control sample in sandy loam soil was found higher than the clay soil. The reason for this is considered to be due to bonding of clay colloids and humus complexes (Sollins et al. 1996; Six et al. 1998). 
(A) Clay soil

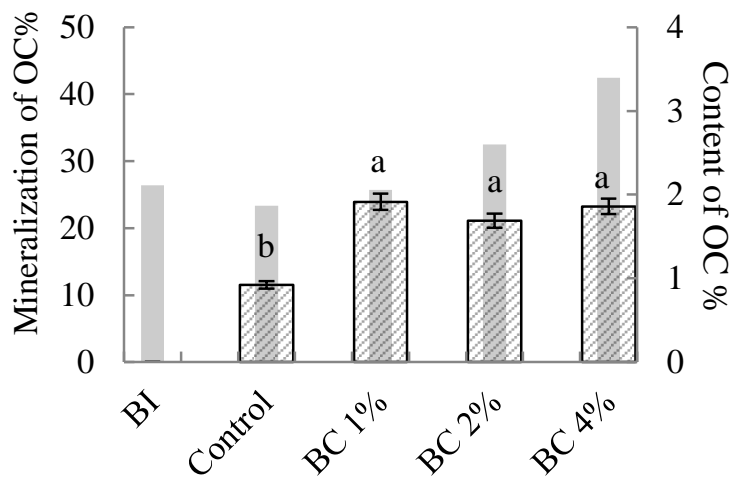

(B) Sandy loam soil

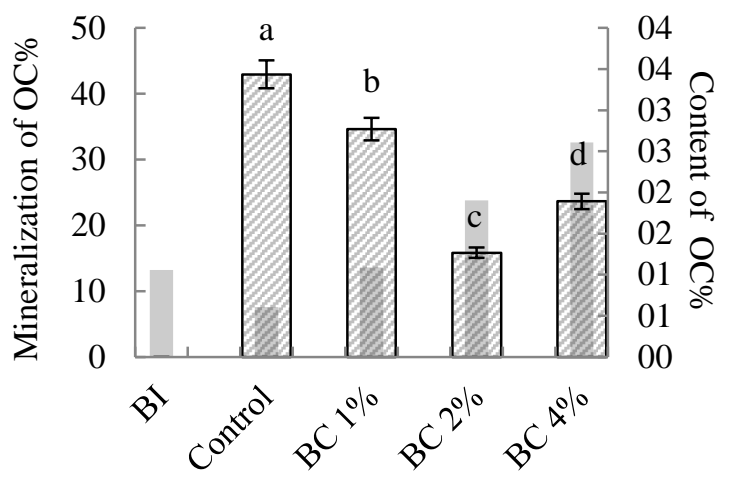

Figure 3

Illustration the effect of incubation period on mineralization of organic carbon in clay and sandy loam soils; BI (Before incubation)

This study was carried out under laboratory condition to investigate the effect of biochar amendment in a short-term period on some soil physico-mechanic and chemical properties. The results obtained showed that BC amendment had a positive effect on soil structural properties, by enhancing soil porosity, reducing BD, and increasing soil aggregation in both soils of study. However, MWD was significantly increased only in clay soil and decreased in sandy loam soil, due to the weak bind between $\mathrm{BC}$ and sand particles. Our results of soil LL test had shown a significant increase with increasing of BC doses in both studied soils. Which could be attributed to the benefits of $\mathrm{BC}$ to promote the soil aggregates and increase the soil porosity, thereby, increasing the soil water storage capacity and raise the liquid limit of soil. The results of PL detected at a clay soil showed the same trend with a significant increase by increase of BC doses. Whereas the results of plastic limits did not show a significant effect because of increase both LL and PL. The chemical properties showed that the benefit of biochar to decrease soil $\mathrm{pH}$ in the study soils, which had relatively high lime content. The $\mathrm{BC}$ additions were increased $\mathrm{C}$ sequestration capacity by significantly increasing of soil OC. The rate of OC mineralization was more at sandy loam soil than clay soil, due to the effect of clay to reducing OC that process, and the mineralization rate still relatively stable even with an increase of BC doses. Whereas in sandy loam soil BC doses were significantly decrease the mineralization rate by increase the sequestration of OC. Although that $\mathrm{BC}$ amendment had a negative effect on soil $\mathrm{EC}$ and $\mathrm{C}: \mathrm{N}$ ratio by raising their values significantly, but generally it improves soil physicomechanic and chemical properties in both soils. Overall, biochar effect was more pronounced on the sandy loam soil than clay soil.

\section{Acknowledgements}

We acknowledge the financial support accorded by the Presidency for Turks Abroad and Related Communities (YTB), Türkiye Scholarship Council, and fund-

ing support provided by the Scientific Research Projects Coordinator (BAP) of Selçuk University via project 18201034, Agriculture faculty, Soil Science and Plant Nutrient Department, Konya. We greatly acknowledge the first author's dispatch organization Department of Tikrit Research, Agricultural Research Office, Ministry of Agriculture, Iraq. We also greatly acknowledge the suggestions by the Editor and reviewers which contributed to the improvement of this paper. This work was summarized from a part of the Ph.D. thesis in Soil Science- Soil Physics of the first author.

\section{References}

ASTM S (2010). Standard test methods for liquid limit, plastic limit, and plasticity index of soils.

Atkinson CJ, Fitzgerald JD, Hipps NA (2010). Potential mechanisms for achieving agricultural benefits from biochar application to temperate soils: a review. Plant and Soil 337 (1): 1-18.

Bal L, Şeker C, Gümüş İ (2011). Kaymak tabakası oluşumuna fizikokimyasal faktörlerin etkileri. Selcuk Journal of Agriculture and Food Sciences, 25(3): 96-103.

Blake GR, Hartge KH (1986). Particle Density. In: Klute, A., Ed., Methods of Soil Analysis, Part 1Physical and Mineralogical Methods", 2nd Edition, Agronomy Monograph 9, American Society of Agronomy-Soil Science Society of America, Madison, WI. pp. 377-382.

Bronick CJ, Lal R (2005). Soil structure and management: a review. Geoderma 124 (1-2): 3-22.

Brown RA, Kercher AK, Nguyen TH, Nagle DC, Ball WP (2006). Production and characterization of synthetic wood chars for use as surrogates for natural sorbents. Organic Geochemistry 37 (3): 321-333.

Cheng CH, Lehmann J, Thies JE, Burton SD, Engelhard MH (2006). Oxidation of black carbon by biotic and abiotic processes. Organic Geochemistry 37 (11): $1477-1488$ 
Chong Lua A, Yang T, Guo J (2004). Effects of pyrolysis conditions on the properties of activated carbons prepared from pistachio-nut shells. Journal of Analytical and Applied Pyrolysis 72: 279-287.

Clough T, Condron L, Kammann C, Müller, C (2013). A review of biochar and soil nitrogen dynamics. Agronomy 3 (2): 275-293.

Danielson RE, Sutherland PL (1986). Porosity. In: Klute, A., Ed., Methods of Soil Analysis, Part 1Physical and Mineralogical Methods", 2nd Edition, Agronomy Monograph 9, American Society of Agronomy-Soil Science Society of America, Madison, WI. pp. 443-461.

Fungo B, Lehmann J, Kalbitz K, Thionǵo M, Okeyo I, Tenywa M, Neufeldt H (2017). Aggregate size distribution in a biochar-amended tropical Ultisol under conventional hand-hoe tillage. Soil and Tillage Research 165: 190-197.

Gee GW, Bauder JW, Klute A (1986). 'Particle-size analysis, In: Klute, A., Ed., Methods of Soil Analysis, Part 1-Physical and Mineralogical Methods", 2nd Edition, Agronomy Monograph 9, American Society of Agronomy-Soil Science Society of America, Madison, WI. pp. 383-411.

Glab T, Palmowska J, Zaleski T, Gondek K (2016). Effect of biochar application on soil hydrological properties and physical quality of sandy soil. Geoderma 281: 11-20.

Graetz RD, Skjemstad J (2003). 'The charcoal sink of biomass burning on the Australian continent.' (CSIRO Atmospheric Research).

Gugino BK, Idowu OJ, Schindelbeck RR, van Es HM, Wolfe DW, Moebius-Clune BN, Thies JE, Abawi GS (2009). 'Cornell Soil Health Assessment Training Manual (Second Edition).' Cornell University, Geneva, New York).

Herath HMSK, Camps-Arbestain M, Hedley MJ, Kirschbaum MUF, Wang T, van Hale R (2015). Experimental evidence for sequestering $\mathrm{C}$ with biochar by avoidance of $\mathrm{CO} 2$ emissions from original feedstock and protection of native soil organic matter. GCB Bioenergy 7 (3): 512-526.

Herath S, Camps Arbestain M, Hedley M (2013). Effect of biochar on soil physical properties in two contrasting soils: An Alfisol and an Andisol.

Ippolito J, Strawn D, Scheckel K, Novak J, Ahmedna M, Niandou M (2011). Biochars impact on soil moisture storage in an Ultisol and two Aridisols. Journal of Environmental Quality 35 (6): 23332341.

Juriga M, Šimanský V (2018). Effect of biochar on soil structure-review. Acta Fytotechnica et Zootechnica 21 (1): 11-19.

Kemper WD, Rosenau RC (1986). Aggregate Stability and Size Distribution1. In: Klute, A., Ed., Methods of Soil Analysis, Part 1-Physical and Mineralogical Methods", 2nd Edition, Agronomy Monograph 9,
American Society of Agronomy-Soil Science Society of America, Madison, WI. pp. 425-441

Koukouzas N, Hämäläinen J, Papanikolaou D, Tourunen A, Jäntti T (2007). Mineralogical and elemental composition of fly ash from pilot scale fluidised bed combustion of lignite, bituminous coal, wood chips and their blends. Fuel 86 (14): 21862193.

Laird DA, Fleming P, Davis DD, Horton R, Wang B, Karlen DL (2010). Impact of biochar amendments on the quality of a typical Midwestern agricultural soil, Geoderma, 158, Issues 3-4: 443-449.

Lehmann J (2007). Bio-energy in the black. Frontiers in Ecology and the Environment 5 (7): 381-387.

Lehmann J, Joseph S (2009). 'Biochar for environmental management: science, technology and implementation.' (Routledge: Earthscan, London).

Lehmann J, Rillig M, Thies J, Masiello CA, Hockaday WC, Crowley D (2011). Biochar effects on soil biota - a review. Soil Biology and Biochemistry 43:1812-1836.

Leonards GA (1962). Foundation engineering. University of Michigan, McGraw-Hill: 1136.

McLean EO (1982). Soil pH and Lime Requirement. In A.L. Page (ed.) Methods of soil analysis". Part 2. 2nd ed. Agron. Monogr. 9. ASA and SSSA, Madison, WI. pp. 199-224.

Minitab (2013). Software (Version 16.2.4, Pennsylvania, USA).

Mitchell JKJ (1976). Fundamentals of Soil Behaviour. Wiley \& Sons, Toronto.

Nelson RE (1982). Carbonate and Gypsum. In 'Methods of Soil Analysis. In A.L. Page (ed.) Methods of soil analysis". Part 2. 2nd ed. Agron. Monogr. 9. ASA and SSSA, Madison, WI. pp. 181-197.

Ningning M, Zhang L, Zhang Y, Yang L, Yu C, Yin G, Doane TA, Wu Z, Zhu P, Ma X (2016). Biochar improves soil aggregate stability and water availability in a mollisol after three years of field application. PLOS ONE 11 (5): e0154091.

Novak JM, Lima I, Xing B, Gaskin JW, Steiner C, Das K, Ahmedna M, Rehrah D, Watts DW, Busscher WJ (2009). Characterization of designer biochar produced at different temperatures and their effects on a loamy sand. Annals of Environmental Science.

Oberlin A (2002). Pyrocarbons. Carbon 40 (1), 7-24.

Omondi MO, Xia X, Nahayo A, Liu X, Korai PK, Pan $G$ (2016). Quantification of biochar effects on soil hydrological properties using meta-analysis of literature data. Geoderma 274 28-34.

Ouyang L, Wang F, Tang J, Yu L, Zhang R (2013). Effects of biochar amendment on soil aggregates and hydraulic properties. Journal of Soil Science and Plant Nutrition 13(4):991-1002.

Peng X, Zhu QH, Xie ZB, Darboux F, Holden NM (2016). The impact of manure, straw and biochar 
amendments on aggregation and erosion in a hillslope Ultisol. CATENA 138: 30-37.

Pituello C, Dal Ferro N, Francioso O, Simonetti G, Berti A, Piccoli I, Pisi A, Morari F (2018). Effects of biochar on the dynamics of aggregate stability in clay and sandy loam soils. European Journal of Soil Science 69 (5): 827-842.

Rajkovich S, Enders A, Hanley K, Hyland C, Zimmerman AR, Lehmann J (2012). Corn growth and nitrogen nutrition after additions of biochars with varying properties to a temperate soil. Biology and Fertility of Soils 48 (3): 271-284.

Rhoades, JD (1982). Soluble Salts1. In A.L. Page (ed.) Methods of soil analysis". Part 2. 2nd ed. Agron. Monogr. 9. ASA and SSSA, Madison, WI. pp.167179.

Six J, Elliott ET, Paustian K, Doran JW (1998). Aggregation and soil organic matter accumulation in cultivated and native grassland soils, Soil Sci. Soc. Am. J., 62:1367-1377.

Sollins P, Homann P, Caldwell BA (1996). Stabilization and destabilization of soil organic matter: mechanisms and controls, Geoderma 74:65-105.

Six J, Bossuyt H, Degryze S, Denef K (2004). A history of research on the link between (micro) aggregates, soil biota, and soil organic matter dynamics. Soil and Tillage Research 79 (1): 7-31.

Six J, Conant RT, Paul EA, Paustian K (2002). Stabilization mechanisms of soil organic matter: Implications for C-saturation of soils. Plant and Soil 241 (2): 155-176.

Six J, Elliott E, Paustian K, Doran J (1998). Aggregation and soil organic matter accumulation in cultivated and native grassland soils. Soil Science Society of America Journal 62 (5): 1367-1377.

Smith HW, Weldon MD (1941). A Comparison of Some Methods for the Determination of Soil Organic Matter1. Soil Science Society of America Journal 5 (C): 177-182.

Sparks DL (2003). Environmental soil chemistry. Academic Press Inc.525 B Street, Suite 1900, San Diego, California.

Şeker C, Manirakiza N, (2020). Effectiveness of compost and biochar in improving water retention char- acteristics and aggregation of a sandy clay loam soil under wind erosion. Carpathian Journal of Earth and Environmental Sciences, 15(1): 5 - 18.

Şeker C, Özaytekin HH, Gümüş İ, Karaarslan E, Karaca Ü (2016). Çumra ovasında önemli ve yaygın üç toprak serisinin toprak kalite indislerinin belirlenmesi, Proje raporu, Program Kodu: 1001, Proje No: 112O314, Konya (in Turkish).

Tammeorg P, Simojoki A, Mäkelä P, Stoddard FL, Alakukku L, Helenius J (2014). Biochar application to a fertile sandy clay loam in boreal conditions: effects on soil properties and yield formation of wheat, turnip rape and faba bean. Plant and Soil 374 (1-2): 89-107.

Tasneem S, Zahir S (2017). Soil respiration, $\mathrm{pH}$ and $\mathrm{EC}$ as influenced by biochar. Soil and Environment 36 (1): 77-83.

Teßin AK (2016). Biochar in soil: Effect on physical, chemical and hydrological properties in differently textured soils. Aarhus Universitet.

TSE (1987). TS 1900 İnşaat mühendisliğinde zemin laboratuar deneyleri. Türk Standartları Enstitüsü, Ankara.

van Bavel CHM (1950). Mean Weight-Diameter of Soil Aggregates as a Statistical Index of Aggregation1. Soil Science Society of America Journal 14 (C): 20-23.

Wang D, Fonte SJ, Parikh SJ, Six J, Scow KM (2017). Biochar additions can enhance soil structure and the physical stabilization of $\mathrm{C}$ in aggregates. Geoderma 303: 110-117.

Woolf D, Amonette JE, Street-Perrott FA, Lehmann J, Joseph S (2010). Sustainable biochar to mitigate global climate change. Nature Communications 1: 56-56.

Wright AF, Bailey JS (2001). Organic carbon, total carbon, and total nitrogen determinations in soils of variable calcium carbonate contents using a Leco CN-2000 dry combustion analyzer. Communications in Soil Science and Plant Analysis, 32 (1920): 3243-3258. 